\section{Analisis Keterampilan Proses Sains Peserta Didik SMA Swasta dengan Akreditasi A Di Kecamatan Sukarami dan Kemuning Palembang}

\author{
Della Tri Anggraini \\ Saleh Hidayat \\ Etty Nurmala Fadillah
}

\begin{abstract}
Abstrak. Tujuan penelitian ini adalah untuk mengetahui persentase keterampilan proses sains peserta didik SMA Swasta akreditasi A di Kecamatan Sukarami dan Kemuning. Penelitian ini merupakan penelitian deskriptif kuantitatif. Sampel dalam penelitian ini adalah SMA Swasta dengan akreditasi A di empat sekolah di Kecamatan Sukarami dan Kemuning. Teknik pengambilan sampel Purposive Sampling. Pengumpulan data menggunakan kuesioner, wawancara, observasi, tes soal pilihan ganda beralasan, dan dokumentasi. Hasil penelitian didapatkan persentase hasil analisis keterampilan proses sains di Kecamatan Sukarami 63,22\% (tinggi) dan Kemuning 61,25\% (tinggi). Kecamatan Sukarami memperoleh persentase perindikator yaitu mengamati $71,72 \%$, mengelompokkan $67,42 \%$, menafsirkan $67,68 \%$, meramalkan $70,71 \%$, merumuskan hipotesis 57,07\%, merencanakan percobaan 55,05\%, dan mengkomunikasikan 44,44\%. Kecamatan Kemuning memperoleh persentase perindikator yaitu mengamati 69,22\%, mengelompokkan 65,52\%, menafsirkan 65,46\%, meramalkan 70,43\%, merumuskan hipotesis 50,47\%, merencanakan percobaan $51,55 \%$, dan mengkomunikasikan $47,85 \%$.
\end{abstract}

Kata Kunci: keterampilan proses sains, kecamatan sukarami dan kemuning, peserta didik sma.

\section{Pendahuluan}

Perkembangan ilmu pengetahuan dan teknologi yang semakin pesat menyebabkan arus informasi menjadi cepat dan tanpa batas. Hal ini berdampak langsung pada berbagai bidang kehidupan, termasuk dalam bidang pendidikan. Seiring perkembangan di abad ke-21 pendidikan menuntut peserta didik untuk menyelesaikan masalah melalui ilmu pengetahuan yang mereka peroleh serta memberi kesempatan untuk dapat mengambil keputusan berdasarkan bukti yang diperoleh dari proses ilmiah dalam menyelesaikan masalah pada kehidupan kesehariannya. Menurut Prabawati \& Rohandi (2015), pendidikan merupakan salah satu bagian penting dalam pembangunan nasional, karena pendidikan merupakan salah satu sarana untuk meningkatkan kualitas sumber daya manusia. Melalui pendidikan potensi manusia akan tumbuh dan berkembang menjadi insan yang tertata pola pikirnya, sikap, dan tingkah laku baiknya. Pendidikan yang berkualitas akan menghasilkan sumber daya manusia yang berkualitas pula, dan sumber daya manusia yang berkualitas mampu menghadapi tantangan kehidupan untuk penyesuaian diri pada perubahan zaman. Pembelajaran Biologi merupakan salah satu mata pelajaran yang di dalamnya terdapat banyak sekali konsep, bukan sekedar dihafalkan namun perlu dipahami dan ditemukan. Pada pembelajaran Biologi di sekolah terbagi dalam dua bagian yaitu sains sebagai produk dan sains sebagai proses. Sains sebagai produk adalah

\section{Biology Teaching and Learning}

ISSN 2621 - 5527

Abstract. The objective of this study is to determine the percentage of science process skills of private A accredited high school students in Kecamatan Sukarami and Kemuning. The researcher used descriptive-quantitative method.The sample were the tenth grade students of private high school with $A$ acreditation in four school in Kecamatan Sukarami and Kemuning.The sample was chosen by using Purposive sampling. The data were obtained by using questionnaires, interviews, observations, multiple choice questions, and documentation. The results showed the percentage of the analysis of science process skills in Kecamatan Sukarami 63.22\% (high) and Kemuning $61.25 \%$ (high). Kecamatan Sukarami obtained the percentage of indicators namely observing $71.72 \%$, classifying $67.42 \%$, interpreting $67.68 \%$, forecasting $70.71 \%$, formulating a hypothesis $57.07 \%$, planning an experiment $55.05 \%$, and communicating 44.44\%. Kecamatan Kemuning obtained the percentage of indicators namely observing $69.22 \%$, grouping $65.52 \%$, interpreting $65.46 \%$, forecasting $70.43 \%$, formulating a hypothesis $50.47 \%$, planning an experiment $51.55 \%$, and communicating $47.85 \%$

Keywords: science process skill, kecamatan sukarami and kemuning, high school students.

Della Tri Anggraini Universitas Muhammadiyah Palembang Indonesia

Saleh Hidayat Universitas Muhammadiyah Palembang Indonesia

Etty Nurmala Fadillah Universitas Muhammadiyah Palembang Indonesia 
pengajaran tentang teori, prinsip dan hukum alam, sedangkan sains sebagai proses adalah pengembangan kemampuan peserta didik dalam metode ilmiah dan pemecahan masalah sains.

Berdasarkan standar isi yang termuat dalam Permendiknas No. 22 tahun 2006, mata pelajaran Biologi di SMA/MA bertujuan agar peserta didik memiliki kemampuan dan keterampilan untuk memperoleh pengalaman dalam menerapkan metode ilmiah salah satunya yaitu keterampilan proses sains. Hal ini menjadi alasan mengapa keterampilan proses sains perlu dimiliki peserta didik karena dalam pembelajaran Biologi, peserta didik tidak hanya diperlukan pengetahuan konseptual tetapi juga kemampuan prosedural seperti keterampilan proses peserta didik agar peserta didik memiliki persiapan dan latihan dalam menghadapi kenyataan hidup di masyarakat dan dilatih untuk berpikir logis dalam memecahkan suatu masalah.

Penelitian ini dilakukan di Kecamatan Sukarami dan Kecamatan Kemuning berdasarkan data dari Badan Akreditasi Nasional Sekolah Menengah Atas (BAN-SM, 2016) sekolah di Kecamatan Sukarami untuk jenjang SMA hanya terdapat 1 sekolah swasta akreditasi A. Pada Kecamatan Kemuning terdapat 6 sekolah swasta akreditasi A dengan tujuan untuk melihat keterampilan proses sains peserta didik pada kedua daerah tersebut. Sekolah yang telah terakreditasi A mengacu pada sarana prasarana, mutu belajar peserta didik, dan kualitas kinerja guru dalam mengajar. Serta dalam pelaksanaan keterampilan proses sains seharusnya sudah berjalan dengan baik.

Kenyataan yang terjadi di lapangan guru mengukur keterampilan proses sains dengan menggunakan lembar observasi. Pada saat pelaksanaannya terdapat banyak kendala karena dalam mengobservasi peserta didik, guru tidak mampu untuk melihat satu persatu aktivitas yang dilakukan oleh peserta didik. Selanjutnya, pada proses pembelajaran di kelas guru sering memberikan penjelasan konsep secara langsung dibandingkan membangun konsep melalui pertanyaan pada peserta didik. Apabila kegiatan pembelajaran terus-menerus seperti ini maka akan menimbulkan ketidaktahuan peserta didik mengenai proses dari konsep materi pembelajaran yang diperoleh sehingga menyebabkan keterampilan proses sains peserta didik tidak optimal. Salah satu cara untuk mengukur keterampilan proses sains tanpa lembar observasi adalah dengan menggunakan soal pilihan ganda beralasan. Berdasarkan latar belakang tersebut, maka dilakukan penelitian dengan judul "Analisis Keterampilan Proses Sains Peserta Didik SMA Swasta dengan Akreditasi A di Kecamatan Sukarami dan Kemuning Palembang".

\section{Metode Penelitian}

\section{Rancangan Penelitian}

Penelitian ini merupakan penelitian deskriptif kuantitatif yang bertujuan untuk menganalisis hasil keterampilan proses sains peserta didik di SMA swasta dengan akreditasi A di Kecamatan Sukarami dan Kemuning. Data kuantitatif diperoleh dari hasil tes dengan menggunakan soal pilihan ganda beralasan untuk menganalisis keterampilan proses sains peserta didik.

\section{Sampel Penelitian}

Pengambilan sampel menggunakan teknik Purposive Sampling berdasarkan kriteria sekolah swasta terakreditasi A. Sampel pada penelitian ini yaitu 4 SMA Swasta akreditasi A di Kecamatan Sukarami dan Kemuning. Responden yang diambil dari 4 sekolah kelas X IPA berjumlah 281 peserta didik.

\section{Instrumen Penelitian}

Instrumen penelitian berupa tes dan nontes. Instrumen tes menggunakan 17 soal pilihan ganda beralasan yang telah dikembangkan oleh Hidayat, Harfian, \& Fadillah tahun 2018. Intrumen nontes menggunakan kuesioner, wawancara, observasi, dan dokumentasi. 
Analisis Keterampilan Proses Sains Peserta Didik SMA Swasta dengan Akreditasi A

Di Kecamatan Sukarami dan Kemuning Palembang

(hlm. 62-70)

\section{Analisis Data}

Teknik analisis data deskriptif kuantitatif dalam bentuk persentase, tujuannya untuk mengetahui persentase penguasaan peserta didik terhadap hasil analisis keterampilan proses sains. Analisis data dilakukan dengan menghitung skor per indikator. Rumus yang digunakan untuk mendapatkan skor persentase tingkat keterampilan proses sains diadaptasi dari Purwanto (2006) sebagai berikut.

Keterangan:

$$
\mathrm{NP}=\frac{\mathrm{R}}{\mathrm{SM}} \times 100 \%
$$

$\mathrm{NP} \quad=$ nilai persentase per indikator keterampilan proses sains

$\mathrm{R} \quad=$ skor yang diperoleh pada indikator keterampilan proses sains

$\mathrm{SM} \quad=$ skor maksimum pada indikator keterampilan proses sains

Tingkat penguasaan keterampilan proses sains dibagi menjadi lima kategori, yaitu sangat tinggi, tinggi, sedang, rendah, dan sangat rendah. Kategori ini diadaptasi dari Azwar (2014) seperti yang ditunjukkan pada Tabel 1 .

Tabel 1. Kategori Penguasaan Keterampilan Proses Sains

\begin{tabular}{|c|c|c|}
\hline No & Persentase Rerata Skor (\%) & Kategori \\
\hline 1 & $75,05<\mathrm{X}$ & Sangat Tinggi \\
\hline 2 & $58,35<\mathrm{X} \leq 75,05$ & Tinggi \\
\hline 3 & $41,65<\mathrm{X} \leq 58,35$ & Sedang \\
\hline 4 & $24,95<\mathrm{X} \leq 41,65$ & Rendah \\
\hline 5 & $\mathrm{X} \leq 24,95$ & Sangat Rendah \\
\hline
\end{tabular}

\section{Hasil Penelitian}

\section{Keterampilan Proses Sains Peserta Didik SMA Swasta di Kecamatan Sukarami}

Analisis keterampilan proses sains peserta didik SMA swasta terakreditasi A di Kecamatan Sukarami menggunakan soal pilihan ganda beralasan. Setiap soal mewakili setiap indikator keterampilan proses sains, hasil analisis deskriptif disajikan pada tabel 2 berdasarkan 7 indikator keterampilan proses sains.

Tabel 2. Keterampilan Proses Sains Peserta Didik SMA Swasta Di Kecamatan Sukarami

\begin{tabular}{|c|l|c|c|}
\hline No & \multicolumn{1}{|c|}{ Indikator } & Persentase (\%) & Kategori \\
\hline 1 & Mengamati & 71,72 & Tinggi \\
\hline 2 & Mengelompokkan & 67,42 & Tinggi \\
\hline 3 & Menafsirkan & 67,68 & Tinggi \\
\hline 4 & Meramalkan & 70,71 & Tinggi \\
\hline 5 & Merumuskan Hipotesis & 57,07 & Sedang \\
\hline 6 & Merencanakan Percobaan & 55,05 & Sedang \\
\hline 7 & Mengkomunikasikan & 44,44 & \\
\hline
\end{tabular}

Berdasarkan tabel 2 terlihat pada indikator mengamati, mengelompokkan, menafsirkan dan meramalkan memiliki kategori tinggi, sedangkan indikator merumuskan hipotesis, merencanakan percobaan dan mengkomunikasikan mendapatkan kategori sedang. Hal tersebut terangkum dalam Gambar 1 berikut. 


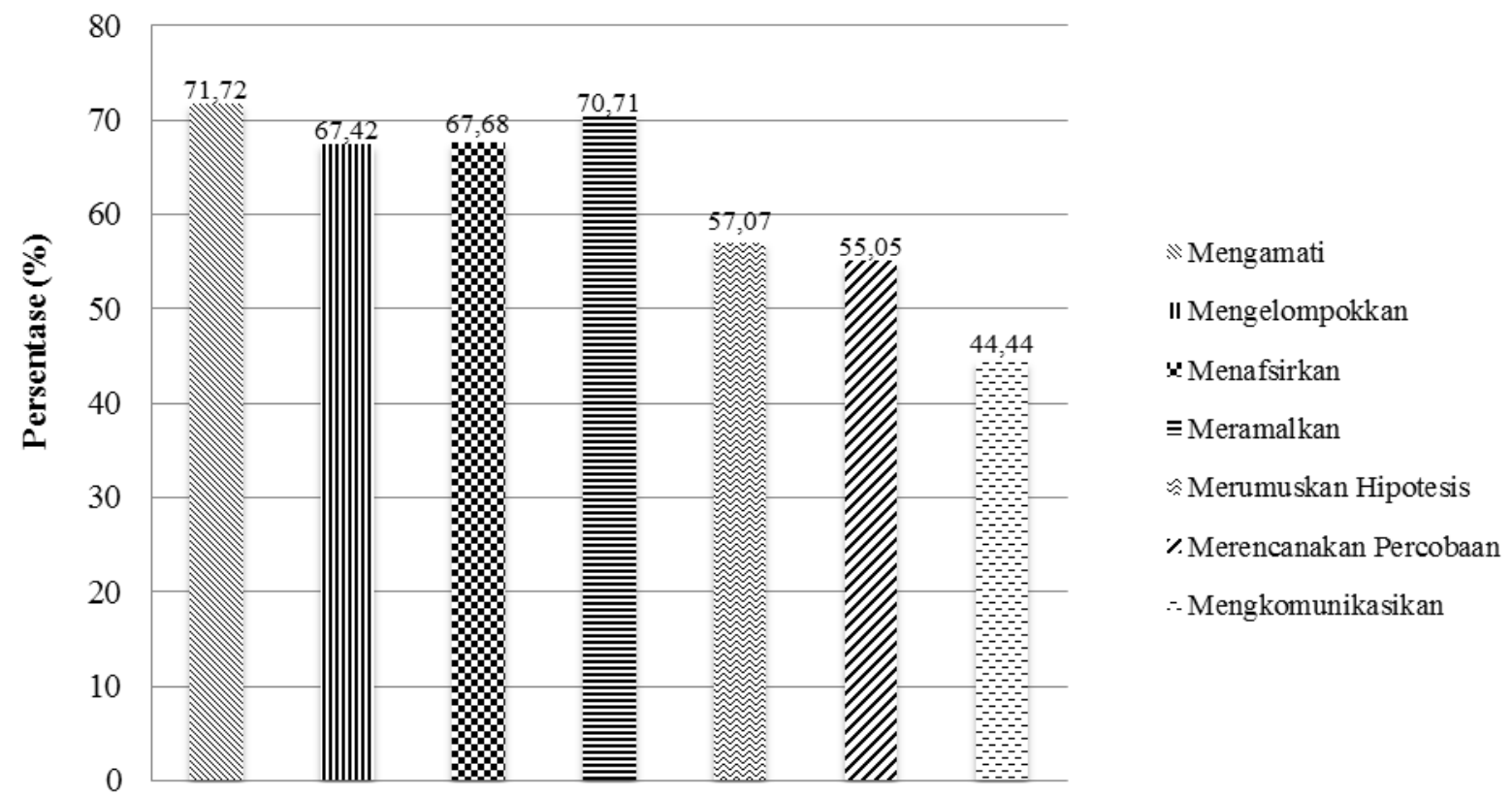

\section{Gambar 1. Keterampilan Proses Sains Peserta Didik SMA Swasta Di Kecamatan Sukarami}

Berdasarkan Gambar 1 terlihat hasil persentase rerata setiap indikator keterampilan proses sains peserta didik SMA, didapatkan persentase keterampilan proses sains peserta didik per indikator yaitu mengamati sebesar $71,72 \%$ dengan kategori tinggi, mengelompokkan 67,42\% dengan kategori tinggi, menafsirkan 67,68\% dengan kategori tinggi, meramalkan $70,71 \%$ dengan kategori tinggi. Pada Gambar 1 indikator yang memperoleh persentase sedang yaitu merumuskan hipotesis sebesar 57,07\%, merencanakan percobaan 55,05\% dan mengkomunikasikan 44,44\%.

\section{Keterampilan Proses Sains Peserta Didik SMA Swasta di Kecamatan Kemuning}

Hasil perhitungan keterampilan proses sains peserta didik SMA di Kecamatan Kemuning dari 3 sekolah swasta terakreditasi A per indikator disajikan pada tabel 3.

Tabel 3. Keterampilan Proses Sains Peserta Didik SMA Swasta Di Kecamatan Kemuning

\begin{tabular}{|c|l|c|c|}
\hline No & \multicolumn{1}{|c|}{ Indikator } & Persentase (\%) & Kategori \\
\hline 1 & Mengamati & 69,22 & Tinggi \\
\hline 2 & Mengelompokkan & 65,52 & Tinggi \\
\hline 3 & Menafsirkan & 65,46 & Tinggi \\
\hline 4 & Meramalkan & 70,43 & Tinggi \\
\hline 5 & Merumuskan Hipotesis & 50,47 & Sedang \\
\hline 6 & Merencanakan Percobaan & 51,55 & Sedang \\
\hline 7 & Mengkomunikasikan & 47,85 & Sedang \\
\hline
\end{tabular}

Pada tabel 3 menunjukkan bahwa keterampilan proses sains peserta didik SMA swasta akreditasi A di Kecamatan Kemuning pada indikator mengamati, mengelompokkan, menafsirkan, dan meramalkan memiliki kategori tinggi, sedangkan untuk indikator merumuskan hipotesis, merencanakan percobaan dan mengkomunikasikan memiliki kategori sedang. Hasil tersebut terangkum dalam Gambar 2. 
Analisis Keterampilan Proses Sains Peserta Didik SMA Swasta dengan Akreditasi A

Di Kecamatan Sukarami dan Kemuning Palembang

(hlm. 62-70)

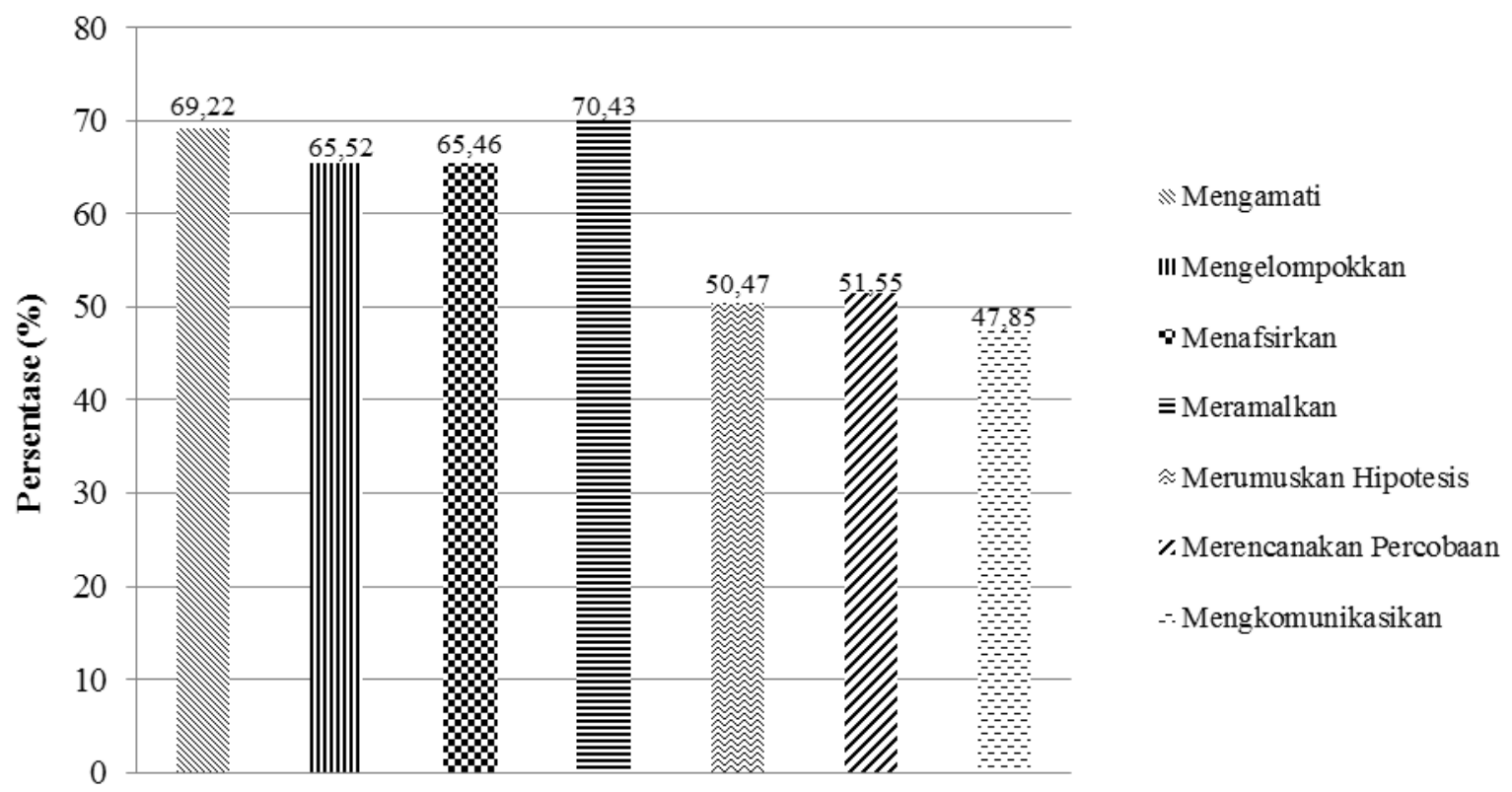

\section{Gambar 2. Keterampilan Proses Sains Peserta Didik SMA Swasta di Kecamatan Kemuning}

Berdasarkan Gambar 2, persentase keterampilan proses sains peserta didik SMA swasta akreditasi A pada Kecamatan Kemuning setiap indikatornya yaitu mengamati sebesar 69,22\%, mengelompokkan sebesar 65,52\%, menafsirkan sebesar 65,46\%, dan indikator meramalkan sebesar 70,43\% dengan kategori tinggi, sedangkan untuk indikator kategori sedang yaitu indikator merumuskan hipotesis sebesar 50,47\%, merencanakan percobaan sebesar $51,55 \%$ dan mengkomunikasikan sebesar 47,85\%.

\section{Pembahasan}

\section{Keterampilan Proses Sains Peserta Didik SMA Swasta Akreditasi A Berdasarkan Setiap Indikator di Kecamatan Sukarami}

Berdasarkan hasil analisis data terlihat bahwa keterampilan mengamati peserta didik SMA di Kecamatan Sukarami memiliki persentase tinggi. Hal ini menunjukkan peserta didik SMA di Kecamatan Sukarami tidak mengalami kesulitan dalam indikator mengamati, karena indikator ini merupakan salah satu indikator keterampilan proses sains paling dasar. Berdasarkan hasil observasi, keterampilan mengamati peserta didik SMA di Kecamatan Sukarami cukup baik, karena pada saat proses pembelajaran guru mengajak peserta didik mengamati suatu objek yang melibatkan panca indera. Peserta didik diarahkan dalam melakukan pengamatan berupa gambar dan informasi bacaan yang ada pada buku pelajaran. Hal tersebut membiasakan peserta didik dalam melakukan kegiatan mengamati untuk menemukan informasi berdasarkan fakta dari kegiatan mengamati tersebut. Hal ini sesuai dengan hasil penelitian Lepiyanto (2014) bahwa keterampilan mengamati berada pada kategori tinggi, karena peserta didik mengamati untuk mengumpulkan data berdasarkan faktor yang terkait dengan materi pembelajaran.

Iqbalia (2015) menyatakan pengembangan keterampilan proses sains harus memungkinkan peserta didik dapat melakukan pengamatan dengan seluruh panca inderanya agar proses pengamatan dapat berjalan dengan baik. Berdasarkan hasil wawancara bahwa peserta didik sudah terbiasa melakukan pengamatan secara langsung di kelas, peserta didik membawa objek untuk melakukan pengamatan yang melibatkan penggunaan alat indera dengan baik dan benar. Hal ini sesuai dengan hasil penelitian Andriani (2017) yang menyatakan tingginya keterampilan mengamati, karena kegiatan mengamati mudah dilakukan oleh peserta didik dan peserta didik sudah terbiasa melakukan kegiatan mengamati dalam kehidupan sehari-hari. 
Pada Kecamatan Sukarami, indikator yang memperoleh persentase terendah yaitu mengkomunikasikan sebesar 44,44\% dengan kategori sedang. Pada keterampilan mengkomunikasikan peserta didik belum mampu menyampaikan informasi melalui gambar, grafik atau diagram. Hal ini tercermin dari hasil tes peserta didik dalam menjawab soal indikator mengkomunikasikan terdapat gambar jaring-jaring makanan dan bagan siklus biogeokimia. Berdasarkan hasil wawancara guru juga menyatakan bahwa peserta didik sulit untuk memahami gambar-gambar, tabel, dan grafik yang ada pada buku pelajaran. Hal ini mendukung hasil penelitian Tuada \& Gunawan (2017), bahwa kemampuan mengkomunikasikan peserta didik tergolong rendah karena peserta didik masih sulit untuk mengungkapkan ide atau pemikiran atas suatu permasalahan dan kurang terlatih dalam membaca gambar atau grafik yang diperoleh.

Rendahnya keterampilan mengkomunikasikan peserta didik di Kecamatan Sukarami dapat disebabkan kurangnya motivasi peserta didik dan teknik mengajar yang kurang menarik. Berdasarkan hasil observasi, saat memulai proses pembelajaran guru tidak memberikan motivasi kepada peserta didik melainkan guru langsung memberikan materi pelajaran. Hal ini menyebabkan peserta didik tidak memiliki rasa percaya diri dalam berinteraksi dan menyampaikan informasi kepada teman sekolahnya. Akibatnya, peserta didik belum memiliki kesiapan dalam menerima materi pelajaran yang disampaikan guru serta peserta didik tidak fokus pada saat proses pembelajaran berlangsung, dan akhirnya guru menerapkan pembelajaran dengan metode ceramah. Didukung oleh hasil penelitian Lanani (2013) yang menyatakan bahwa sebelum memulai proses pembelajaran guru perlu mendesain pembelajaran yang akan diterapkannya, seperti kesiapan dan motivasi, alat penarik perhatian, partisipasi aktif peserta didik, dan menghindari materi yang tidak relevan.

\section{Keterampilan Proses Sains Peserta Didik SMA Swasta Akreditasi A Berdasarkan Setiap Indikator di Kecamatan Kemuning}

Hasil dari analisis data terlihat bahwa keterampilan meramalkan peserta didik SMA di Kecamatan Kemuning memperoleh persentase tertinggi. Hal ini dikarenakan peserta didik SMA sudah mampu memperkirakan sesuatu yang akan terjadi berdasarkan pengetahuan yang sudah ada untuk menjawab pertanyaan yang berhubungan antara fakta, konsep, dan prinsip dalam ilmu pengetahuan. Berdasarkan hasil tes soal pilihan ganda beralasan, peserta didik dapat menjawab pertanyaan pada indikator meramalkan. Hal ini mendukung hasil wawancara bahwa sebelum mengerjakan soal tes, selama proses pembelajaran peserta didik telah difasilitasi 1 buku paket 1 orang, sehingga peserta didik telah memiliki informasi mengenai alat dan bahan yang diperlukan saat akan melakukan percobaan di lingkungan biotik dan abiotik, serta memiliki kemampuan meramalkan interaksi yang terjadi antar komponen makhluk hidup. Sesuai dengan penelitian Solihati (2015), memperoleh indikator memprediksi tinggi karena, peserta didik sudah mampu memperkirakan sesuatu yang akan terjadi berdasarkan suatu kecenderungan atau pola yang sudah ada untuk menjawab pertanyaan. Selanjutnya, menurut Salosso, Nurlaili, \& Kusumawardani (2018), peserta didik mampu meramalkan dengan baik disebabkan karena sebelumnya peserta didik telah mendapatkan pemahaman konsep.

Tingginya keterampilan memprediksi di Kecamatan Kemuning dikarenakan sudah menerapkan pembelajaran dengan metode diskusi. Pada kegiatan diskusi peserta didik dapat menguasai konsep, berinteraksi lebih dekat antara kelompok, dan bekerjasama dalam memecahkan sebuah permasalahan. Berdasarkan hasil observasi pada saat proses pembelajaran di kelas, guru meminta peserta didik berdiskusi dengan teman sebangkunya untuk meramalkan peristiwa yang akan terjadi berdasarkan pengalaman sebelumnya. Peserta didik juga dapat diarahkan guru untuk memprediksi suatu permasalahan dengan menggunakan fakta-fakta dari proses pembelajaran yang sedang berlangsung. Hal ini sesuai dengan hasil penelitian Nelyza, Hasan, \& Musman (2015), menyatakan bahwa indikator meramalkan mengalami peningkatan tertinggi dikarenakan pada saat proses pembelajaran berlangsung, peserta didik diajarkan menemukan sendiri dari hasil diskusi. Selanjutnya, menurut Titin (2013), keterampilan memprediksi berapa pada kategori baik, karena 
(hlm. 62-70)

peserta didik mampu untuk menggunakan pola-pola hasil pengamatan untuk menjawab pertanyaan dengan kemampuan menalar.

Pada indikator mengkomunikasikan di Kecamatan Kemuning mendapatkan persentase terendah yaitu sebesar 47,85\% dengan kategori sedang. Hal ini dikarenakan peserta didik kurang mampu memahami gambar-gambar dalam pembelajaran Biologi. Berdasarkan hasil observasi bahwa peserta didik tidak aktif pada saat guru memberikan pertanyaan, dan kondisi suasana kelas yang membosankan. Hal ini terjadi karena guru menjelaskan materi terlalu banyak, sehingga peserta didik mengantuk, dan peserta didik belum mampu menjelaskan ulang gambar-gambar pada powerpoint secara lisan di depan kelas. Hal ini sesuai dengan hasil penelitian Komikesari (2016), bahwa sebagian besar peserta didik kurang percaya diri dalam berkomunikasi ketika menggambarkan data, baik dalam bentuk grafik atau tabel, dan peserta didik tampak gugup terutama saat menjelaskan data secara lisan.

Rendahnya aspek mengkomunikasikan juga disebabkan karena peserta didik belum mampu memahami gambar, grafik, dan tabel pada pembelajaran Biologi. Hal ini sesuai dengan hasil wawancara kepada guru yang menyatakan bahwa peserta didik sulit untuk memahami gambar, grafik, dan tabel pada saat pelajaran Biologi. Didukung oleh hasil penelitian Zulfatin (2014), faktor penyebab rendahnya kemampuan mengkomunikasikan peserta didik yaitu peserta didik belum terbiasa untuk mengkomunikasikan hasil dengan benar. Keterbatasan peserta didik dalam memahami, membaca grafik, dan menganalisis. Rendahnya kemampuan berkomunikasi juga dikemukakan oleh Salosso, Nurlaili, \& Kusumawardani (2018), dalam menyampaikan hasil peserta didik lebih banyak diam dibandingkan menjawab pertanyaan.

\section{Kesimpulan}

Berdasarkan penelitian yang telah dilakukan dapat ditarik kesimpulan persentase keterampilan proses sains peserta didik SMA kelas X di Kecamatan Sukarami memperoleh persentase keterampilan proses sains di Kecamatan Sukarami dengan indikator tertinggi yaitu mengamati $71,72 \%$ dan terendah yaitu mengkomunikasikan 44,44\%. Persentase keterampilan proses sains peserta didik SMA kelas X di Kecamatan Kemuning dengan indikator tertinggi yaitu meramalkan 70,43\% dan terendah yaitu mengkomunikasikan $47,85 \%$.

\section{Ucapan Terima Kasih}

Terima kasih kepada team PSN, kepada Dr. Saleh Hidayat, M.Si., Binar Azwar Annas Harfian, S.Pd., M.Pd., dan Etty Nurmala Fadillah, S.Pd., M.Pd., atas bimbingan yang diberikan selama kegiatan penelitian. Kepada guru-guru Biologi di SMA Swasta di Kecamatan Sukarami dan Kemuning yang telah memberikan bantuan dan dukungan untuk melaksanakan penelitian di sekolahnya.

\section{Referensi}

Andriani. (2017). Meningkatkan Keterampilan Proses Sains dan Hasil Belajar Kelas VII C SMP Negeri 1 Kusan Hilir dengan Pendekatan Saintifik pada Konsep Ekosistem. Jurnal Pendidikan Hayati. 3 (1).

Azwar, S. (2014). Penyusunan Skala Psikologi. Yogyakarta: Pustaka Pelajar.

BAN-SM. (2016). Hasil Akreditasi SMA/MA Kota Palembang. Palembang: Dinas Pendidikan Kota.

Iqbalia, F. (2015). Analisis Keterampilan Proses Sains Siswa pada Model Pembelajaran Predict, Observer, Explain (POE) pada Materi Asam Basa. Jakarta: Program Studi Pendidikan Kimia Jurusan Pendidikan Ilmu Pengetahuan Alam Fakultas Ilmu Tarbiyah dan Keguruan Universitas Islam Negeri Syarif Hidayatullah Jakarta. 
Komikesari, H. (2016). Peningkatan Keterampilan Proses Sains dan Hasil Belajar Fisika Siswa pada Model Pembelajaran Kooperatif Tipe Student Team Achievement Division. Jurnal Keguruan dan Ilmu Tarbiyah. 1 (1).

Lanani, Karman. (2013). Belajar Berkomunikasi dan Komunikasi untuk Belajar dalam Pembelajaran Matematika. Jurnal Imiah Program Studi Matematika STKIP Siliwangi Bandung. 2 (1).

Lepiyanto, A. (2014). Analisis Keterampilan Proses Sains pada Pembelajaran Berbasis Praktikum. Jurnal Pendidikan Biologi (BIOEDUKASI), 5 (2).

Nelyza, F., Hasan, M., \& Musman, M. (2015). Implementasi Model Discovery Learning pada Materi Laju Reaksi untuk Meningkatkan Keterampilan Proses Sains dan Sikap Sosial Peserta Didik Mas Ulumul Qur'an Banda Aceh. Jurnal Pendidikan Sains Indonesia. 3 (2) 12-21.

Peraturan Menteri Pendidikan Nasional No. 22 Tahun (2006) Standar Isi untuk Satuan Pendidikan Dasar dan Menengah. (Online). (http://www.aidsindonesia.or.id/uploads/ 20130729141205.Permendiknas_No_22_Th_2006.pdf).

Prabawati, W. R. (2015). Keterampilan Proses Sains Guru IPA . Prosiding Pertemuan Ilmiah XXIX HFI Jateng \& DIY. (25-27).

Purwanto, N. (2006). Prinsip-prinsip dan Teknik Evaluasi Pengajaran. Bandung: PT. Remaja Rosdakarya.

Salosso, W. S, Nurlaili \&, Kusumawardani, R. (2018). Analisis Keterampilan Proses Sains Siswa SMA melalui Penerapan Model Pembelajaran Learning Cycle 5E pada Pokok Bahasan Larutan Asam Basa. Bivalen: Chemical Studies Journal. 1 (1).

Solihati, B., Achmad, A., \& Yolida, B. (2015). Profil Keterampilan Proses Sains pada Materi Sistem Gerak Manusia. Jurnal Bioterdidik. 2 (5).

Titin. (2013). Deskripsi Keterampilan Proses Sains Mahasiswa Pendidikan Biologi melalui Pembelajaran Berbasis Praktikum pada Mata Kuliah Taksonomi Tumbuhan. Jurnal Pendidikan Matematika dan IPA. 4 (1) 47-52.

Tuada, R., \& Gunawan, S. (2017). Pengaruh Model Pembelajaran Generatif dengan Teknik Guided Teaching terhadap Keterampilan Proses Sains. Jurnal Pendidikan Fisika dan Teknologi. 3 (2).

Zulfatin, V. (2014). Profil Keterampilan Proses Sains SIswa SMA dalam Kegiatan Praktikum Materi Elastisitas yang Dinilai Menggunakan Penilaian Kinerja. Bandung: Jurusan Pendidikan Fisika Fakultas Pendidikan Matematika dan Ilmu Pengetahuan Alam Universitas Pendidikan Indonesia. 
70 Jurnal Biology Teaching and Learning, Volume 1, Nomor 1, Juni 2018

Analisis Keterampilan Proses Sains Peserta Didik SMA Swasta dengan Akreditasi A

Di Kecamatan Sukarami dan Kemuning Palembang

(hlm. 62-70)

\begin{tabular}{|l|l|l|}
\hline Della Tri Anggraini & $\begin{array}{l}\text { S.Pd, Mahasiswa Jurusan Pendidikan Biologi, FKIP Universitas } \\
\text { Muhammadiyah Palembang, Jl. Jenderal A. Yani 13 Ulu Palembang } \\
\text { 30263, Indonesia. } \\
\text { E-mail: Dellaaata@gmail.com }\end{array}$ \\
\hline Saleh Hidayat & $\begin{array}{l}\text { Dr., M.Si., Dosen Jurusan Pendidikan Biologi, FKIP Universitas } \\
\text { Muhammadiyah Palembang, Jl. Jenderal A. Yani 13 Ulu Palembang } \\
\text { 30263, Indonesia. } \\
\text { E-mail: } \underline{\text { salehhidayat29@gmail.com }}\end{array}$ \\
\hline $\begin{array}{l}\text { Etty Nurmala } \\
\text { Fadillah }\end{array}$ & $\begin{array}{l}\text { S.Pd., M.Pd., Dosen Jurusan Pendidikan Biologi, FKIP Universitas } \\
\text { Muhammadiyah Palembang, Jl. Jenderal A. Yani 13 Ulu Palembang }\end{array}$ \\
$\begin{array}{l}\text { 30263, Indonesia. } \\
\text { E-mail: ettynurmalafadillah@um-palembang.ac.id }\end{array}$ & \\
\hline
\end{tabular}

